a time of austerity, they have been handed the ultimate luxury: a new frontier for research that is limited only by their imagination.

Conceived during the cold war, the ISS was born of global politics, and remains a showpiece of international collaboration. An engineering marvel, the orbiting laboratory came within a whisker of cancellation in 1993, yet is expected to remain a bright fixture of the night sky for at least the next decade. It is time for the ISS to show what it can do. So what can it do? "Grow crystals," shout the critics. It is true that the image of research on the space station, and space science more generally, suffers from the limited scope of early experiments. Much of the research carried out on the ISS so far can, perhaps unfairly, be lampooned in a similar way. The impact of the lack of gravity on an experiment often seems to be investigated purely because it can be, rather than because the question has genuine scientific value. The other popular function of the space station's facilities - to probe the effects of weightlessness on its occupants - is based on the circular logic that demands such information as essential for continued human presence in space.

To their credit, those running research on the ISS seem determined to push those boundaries. Last month, the European Space Agency appealed for ideas and 'vision' from scientists to shape its next ISS research programme, due to be presented to member states in 2012. And next week, NASA will hold a public meeting to help throw open the airlock of the ISS to sister government agencies, chemical firms and pharmaceutical companies, among others (see page 610).

NASA is the biggest funder of the ISS and its biggest stakeholder, yet it would be a sensible step for the agency to hand over its control of ISS science to an independent body. Acting as a buffer between

NASA managers and the broader research community who could use the ISS facilities, such a body was first proposed last year in the Augustine committee's review of US human spaceflight plans and was mandated by the NASA authorization bill passed this September. The Space Telescope Science Institute in Baltimore, Maryland, which oversees research on space telescopes such as Hubble, shows how such an operation can work well. If set up properly, a similar body could offer a useful arms-length approach to space science that could boost both the profile and quality of orbiting experiments.

"Flagship shiny projects help to stir wider public interest in science and so loosen political purse strings." This could help to counter continuing accusations that expanded space-station research will merely throw into orbit good money after bad. But for such a strategy to succeed, the scientific demand to drive competition for expensive time aboard the ISS must be there - a condition that is by no means certain. But scientists, whatever their views on its cost effectiveness, should not glibly dismiss the research credentials of the space station and its possible contribution to science. Those with even a passing interest should take the officials in charge at their word and give serious thought to how the facility could be used.

Flagship shiny projects help to stir wider public interest in science and so loosen political purse strings to release funds that might otherwise not flow to research. And basic, blue-skies research, scientists often say, is the bedrock of useful creativity. Decades in the making, the overpriced and underused marvel that is the International Space Station offers bluer skies than most.

\section{Undue obstruction}

\section{Republican opposition to the US-Russia arms- control treaty is based on politics, not science.}

W hen US President Barack Obama signed the latest armscontrol treaty with Russia in April 2010, he called it "an important first step". But the administration has been tripped up by Republican opposition to the New Strategic Arms Reduction Treaty (New START), which would reduce both nations' arsenals by roughly one-third. The Republicans are blocking the treaty with pseudoscientific arguments about the state of the country's weapons complex. Yet it is politics, not science, that is behind their move.

Earlier this week, Arizona senator Jon Kyl, the number-two Republican in the Senate, said he believed that the treaty could not be ratified by the end of the year. Debate over its merits would take "at least two weeks", and Senate Democrats had not provisioned enough time for the discussion, Kyl said on US network NBC's Meet the Press talk show.

Pushing a vote on the treaty into 2011 would present it to a new Senate - containing more Republicans - potentially making it less likely to pass. Such a delay would also increase the chances of Kyl, no fan of arms control, giving the Obama administration a bloody nose.

The debate Kyl hungers for is less about the treaty itself than it is about the state of the US nuclear complex. In a 24 November memo to Senate Republicans, Kyl and Bob Corker (Republican, Tennessee) characterized nuclear-weapons scientists as mechanics working in a decrepit garage on a fleet of 30-year-old Ferraris. The scientists are "responsible for assuring that, at any given moment, each of the eight finely tuned cars will respond to the key turn", they wrote.

Implicit in this analogy is that there is some uncertainty over how the country's decades-old nuclear weapons will behave if they are ever used. Moreover, Kyl implies that weapons scientists are ill-equipped to analyse and diagnose problems associated with the arsenal.
There is little in the open scientific literature to support these positions. The chief concern surrounding ageing nuclear weapons has been that their plutonium triggers will be damaged by self-irradiation. Yet a 2006 review of weapons-lab data by the independent JASON scientific advisory group found that the triggers are heartier than expected and will last for at least 85 years.

Similarly, the image of a rickety garage is hardly appropriate. Weapons scientists have a slew of modern tools to ensure that their weapons continue to work effectively. Last year saw the start-up of the US\$3.5-billion National Ignition Facility, a giant laser at Lawrence Livermore National Laboratory in California that aims to replicate the forces inside an exploding warhead. Livermore's sister lab, Los Alamos National Laboratory in New Mexico, is home to a radiographic facility that can create three-dimensional X-rays of dummy bombs as they explode. And scattered across the weapons complex are powerful supercomputers that can simulate full nuclear explosions based on data from these experiments and from past tests.

The weapons labs want more, and have found an ally in Kyl. Over the summer, the senator conducted tours of the labs, and came away with strengthened demands for funds, including money for modern uranium and plutonium manufacturing facilities. Many of the arguments he uses have been used by some within the weapons complex for years to call for a return to underground testing, as well as the development of new kinds of 'reliable' weapons.

The Obama administration had offered Kyl a decade-long funding commitment worth more than $\$ 85$ billion to the weapons complex in exchange for agreement on the treaty, but the senator has continued to advance his flimsy political arguments over the fitness of the country's complex. As Nature went to press, Obama was due to host a bipartisan meeting to try to resolve the dispute.

There is certainly a need to debate the future shape and size of the
DNATURE.COM To comment online, click on Editorials at: go.nature.com/xhunqu US weapons complex, but there is no need to do so before ratifying New START. The facts speak for themselves: the weapons will work, and the scientists watching them have the tools to make sure that they do. 